\title{
Influence of pesticide use on flower formation and fertility of some fruit species
}

\author{
Holb, I. J. \\ Centre of Agricultural Sciences, University of Debrecen, 138 Böszörményi Street, 4032 Debrecen, Hungary
}

Summary: This review evaluated previous studies on the effect of pesticide use on flower formation and fertility of some fruit species. The study was divided into two parts. First part of the overview will evaluate the most commonly used fungicides on pollen toxicity and their germination ability under fungicide exposure on different fruit species. Effect of fungicides on fruit set was also critically reviewed. Second part of the study summarised those few studies which determined the effect of some insecticides and acaricides on flower formation and fertility.

Key words: fungicides, insecticides, acaricides, flower, fertility, fruit

\section{Introduction}

When searching literature on pesticide use affecting fruit tree flowers, it can be seen that most papers paid attention to fungicides affecting flower parts' development and fertility, and a relatively small number of papers dealt with the relationships between insecticides, acaricides or other chemical compounds and flowers.

Therefore, in this sub-chapter, firstly, the effect of several fungicides then insecticides along with other chemical compounds on flowers will be discussed in details.

\section{Effect of fungicides on flower formation and fertility}

Detrimental effects of fungicide sprays on pollen germination, fruit set, and/or yield were reported on apple (Legge \& Williams, 1975; Church \& Williams, 1977, 1978; Brown \& Hendrix, 1978; Ries, 1978; Church et al., 1983ab; Church \& Williams, 1983; Fell et al.,1983; Marcucci \& Filiti, 1984; Butt et al., 1985; Mayer \& Lunden, 1986; Watters \& Sturgeon, 1990; Cooley, 1991; Cooley \& Greene, 1994; Kubik et al., 2000; Yi et al., 2003c), pear (Marcucci \& Filiti, 1984; Butt et al., 1985; Mayer \& Lunden, 1986), sweet cherry (Eaton, 1961), pecan (Wetzstein, 1990; He \& Wetzstein, 1994), peach (Olien et al., 1995) and almond (Yi et al., 2003abc).

As fungicides are applied frequently against apple scab and powdery mildew during the bloom period, several studies examined the effect of different fungicide compounds on pollination, pollen viability, pollen tube growth and fertility. Legge \& Williams (1975) were the first to write down the adverse effect of fungicidal sprays on the pollination of apple flowers. Two years later, Church \&
Williams (1977, 1978) showed that captan, benomyl and thiophanate-methyl inhibited pollen germination of apple in vitro. They were able to show that an in vitro test was effective in assessing the relative toxicity of fungicides and they found good correlations between in vitro and in vivo results on fungicide toxicity. In the same study, authors found that fungicide applications made within 24 hours of pollination were very detrimental to pollination and fruit set. Moreover, Church \& Williams (1977) sprayed handpollinated stigmas with different fungicides either before or after pollination. The results indicated that if pollination occurred two hours before spraying, pollen growth was inhibited, but if pollination occurred two hours after spraying, pollen tubes developed relatively well (Table 1). In addition, Brown \& Hendrix (1978) indicated that the detrimental effect of fungicides on apple pollen germination resulted in lower fruit set.

Church \& Williams (1983) and Church et al., (1983a) clearly demonstrated that captan can dramatically decrease pollen viability of apple. They showed the detrimental effect both under laboratory and field conditions. Among the tested

Table 1 Percent of hand-pollinated stigmas showing adequate pollen tube development sprayed with different fungicides either before or after pollination (adopted from Church \& Williams, 1977)

\begin{tabular}{|l|c|c|c|c|}
\hline \multirow{2}{*}{ Treatments } & \multicolumn{4}{|c|}{ Time of pollination relative to spraying } \\
\cline { 2 - 5 } & $\begin{array}{c}1 \text { day } \\
\text { before }\end{array}$ & $\begin{array}{c}2 \text { hours } \\
\text { before }\end{array}$ & $\begin{array}{c}2 \text { hours } \\
\text { after }\end{array}$ & $\begin{array}{c}1 \text { day } \\
\text { after }\end{array}$ \\
\hline Control & 84 & 79 & 79 & 92 \\
\hline Benomyl & 76 & 67 & 84 & 96 \\
\hline Captan & 88 & 25 & 70 & 84 \\
\hline Dinocap & 84 & 20 & 85 & 64 \\
\hline Thiophanate-methyl & 84 & 80 & 89 & 84 \\
\hline
\end{tabular}


products, captan was the only fungicide that greatly reduced pollen germination in both laboratory and orchard tests (Table 2). Moreover, Church et al. (1983b) also showed that spray volume can also influence the toxicity effect of fungicides to pollen growth. They showed that dilute applications of captan were more toxic to pollens than the 5time-concentrated one. In the following years, similar results were obtained by Fell et al. (1983), Marcucci \& Filiti (1984), Butt et al. (1985) and Mayer \& Lunden (1986) about fungicide effect on pollen germination and viability.

Table 2 Toxicity of fungicides to pollen in vivo and in vitro (adopted from Church et al., 1983a)

\begin{tabular}{|l|l|l|c|c|}
\hline \multirow{2}{*}{ Treatments } & \multicolumn{2}{|c|}{ In vivo } & \multicolumn{2}{c|}{ In vitro } \\
\cline { 2 - 5 } & $\begin{array}{c}\text { Concentration } \\
(\mathrm{kg} / 450 \mathrm{l})\end{array}$ & $\begin{array}{c}\text { Germinated } \\
\text { pollen/stigma }\end{array}$ & $\begin{array}{c}\text { LD50 (amount } \\
\text { needed to kill } \\
50 \% \text { pollen) }\end{array}$ & $\begin{array}{c}\text { Pollen } \\
\text { germination } \\
\text { (\% of control) }\end{array}$ \\
\hline Control & - & 1.9 & - & - \\
\hline Benomyl & $0.9 \mathrm{~kg}$ & 1.5 & 18.1 & 95 \\
\hline Captan & $3.2 \mathrm{~kg}$ & 0.5 & 0.7 & 6 \\
\hline Dodine & $0.18 \mathrm{~kg}$ & 0.3 & 15.7 & 100 \\
\hline $\begin{array}{l}\text { Mancozeb }+ \\
\text { Ziram }\end{array}$ & $3.2+3.2 \mathrm{~kg}$ & 1.5 & 16.3 & 100 \\
\hline Sulphur & $6.7 \mathrm{~kg}$ & 0.1 & 16.5 & 75 \\
\hline
\end{tabular}

The studies of Watters \& Sturgeon (1990) compared the effects of sterol-inhibiting fungicides, dodine and captan on pollen germinations. They also showed that captan was the most toxic to pollen. Dodine was the second most toxic fungicide to pollens. The sterol-inhibiting fungicides did not have a significant effect on pollen germination (Figure 1).

Cooley (1991) concluded that application of captan during bloom may create problems with pollen germination. These results partly explain why some orchards had problems with fruit set, when captan and dodine had been used. Cooley (1991) also suggested that the safest route to take may be to avoid applying any fungicide during good pollination weather. If a fungicide must be used, then one of the less toxic fungicides should be applied. Cooley \& Greene (1994) made direct experiments to know whether captan, copper hydroxide, mineral oil and sterol-inhibiting fungicide sprays affected only pollen germination or also had an influence on fruit set. The results showed that captan and

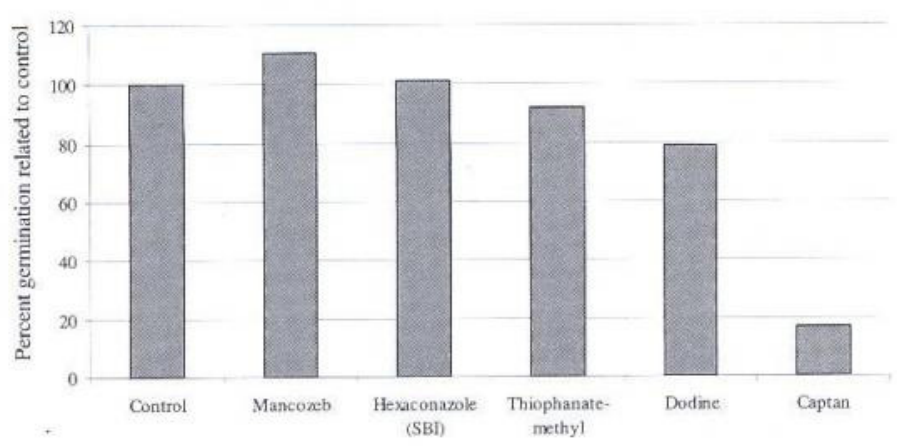

Figure 1 Germination of apple pollens in fungicide laboratory tests (adopted from Watters \& Sturgeon, 1990) fenarimol with or without copper hydroxide applications, did not influence fruit set significantly on cv. 'McIntosh' in New England (Table 3). Moreover, they indicated that timings of captan application did not result in significant reduction of fruit set.

Table 3 Fruit set following treatments of captan, fenarimol, copper hydroxide and their combination on cv. 'McIntosh' in New England (adopted from Cooley \& Greene, 1994)

\begin{tabular}{|l|c|}
\hline Treatments & Fruit set $\left(\right.$ number $\left./ \mathrm{cm}^{2}\right)$ \\
\hline Control & $3.8 \mathrm{a}$ \\
\hline Captan & $5.7 \mathrm{a}$ \\
\hline Fenarimol & $6.7 \mathrm{a}$ \\
\hline Copper hydroxide & $5.7 \mathrm{a}$ \\
\hline Copper hydroxide + Captan & $5.8 \mathrm{a}$ \\
\hline Copper hydroxide + Fenarimol & $5.1 \mathrm{a}$ \\
\hline
\end{tabular}

Kubik et al. (2000) made further experiments on residues of captan (contact) and difenoconazole (systemic) fungicides in bee products from an apple orchard. They placed ten bee colonies in the middle of a ten-hectare-apple orchard at about $10 \%$ in bloom. The orchard was sprayed with a mixture of a captan and difenoconazole fungicides. The residues of fungicides in honey had very low contamination $0.0006 \mathrm{mg} / \mathrm{kg}$ of difenoconazole and $0.009 \mathrm{mg} / \mathrm{kg}$ of captan. Contamination of pollen was much higher (about 0.043 and $2.99 \mathrm{mg} / \mathrm{kg}$ of difenoconazole and captan, respectively). The most contaminated was bee bread, with 0.27 and $6.39 \mathrm{mg} / \mathrm{kg}$ of difenoconazole and captan, respectively. Kubik et al. (2000) also demonstrated that difenoconazole penetrates about 1.66 and 1.16 times more efficiently into honey and bee bread, respectively, than captan. But in pollen pellets from apple, the penetration coefficient was lower than 1 . This observation corroborates the suggestion that in fresh pollen some fungicides may be fixed by sugars, aminoacids, or even proteins. $Y i$ et al. (2003c) evaluated captan, myclobutanil and streptomycin sprays on pollen germination and pollen tube growth. They found that captan significantly reduced pollen germination, by $20 \%$ compared with water controls when pollination was conducted 18 hours after treatment. The number of tubes that reached the basal part of the style within $20 \mathrm{~h}$ was not affected. In contrast, myclobutanil and streptomycin had no significant effect on pollen tube growth.

Fungicide toxicity results on pollens of pear (Marcucci \& Filiti, 1984; Butt et al., 1985; Mayer \& Lunden, 1986) and sweet cherry (Eaton, 1961) were similar to those found in apple.

On the pecan cv. 'Desirable', Wetzstein (1990) and $\mathrm{He}$ \& Wetzstein (1994) studied the effect of six fungicides (dodine, propiconazole, thiophanate-methyl, fentin hydroxide, benomyl and sulphur) on pollen germination Pollen was collected and germinated on pesticide-free media. Fentin hydroxide applied three times a week caused the least inhibition, and reduced germination only in thrice weekly sprays. Dodine, propiconazole and sulphur reduced pollen 
germination the most severely. Fungicides applied during early season growth may contribute to abnormal microspore development, pollen degeneration and retarded development of catkins and leaves.

On peach, Olien et al. (1995) demonstrated that ammonium thiosulphate and fungicides, when applied as tank mixes, could cause burn of blossoms and shoots, but not when applied separately. Nine fungicides, alone and in combination with ammonium thiosulphate were evaluated under commercial orchard conditions. They showed that fruit number per tree was affected only by ammonium thiosulphate and the numbers of blossom blight cankers per tree only by fungicide.

Recently several studies of fungicide toxicity were made on almond pollen ( $Y i$ et al., 2003abc). Almond is a selfincompatible nut crop that has a fruit set of only approx. $30 \%$ of the total number of flowers. Therefore, influence of fungicide sprays on pollens and pollination is of concern, and identification of chemicals having the least detrimental effects would be desirable. $Y i$ et al. (2003a) evaluated the effect of in vitro fungicide sprays (azoxystrobin, myclobutanil, iprodione and cyprodinil) on stigma morphology in almond. They found that azoxystrobin increased exudate accumulation at 4 and 24 hours after spraying, and localized damage and collapse of stigmatic cells were observed after $24 \mathrm{~h}$. Likewise, myclobutanil caused significant damage to and collapse of papillae. Iprodione had no effect on exudate accumulation but caused marked and severe collapse of stigmatic papillae which was pronounced at 24 hours. Cyprodinil promoted a similar increase in exudate secretion and caused the most severe collapse of stigmatic cells of all the fungicides evaluated. In another almond study, effects of in vitro fungicide sprays were evaluated on pollen germination and growth ( $Y i$ et al., 2003b). Captan and azoxystrobin were the most toxic to pollens, the germination percentages were less than $1 \%$ of the untreated control (Table 4). Germination was not

Table 4 Germination and tube growth of almond pollen in a laboratory study of ten fungicides (adopted from $Y i$ et al., 2003b)

\begin{tabular}{|l|c|c|}
\hline Treatmentsa & $\begin{array}{c}\text { Pollen germination } \\
\text { related to control (\%) }\end{array}$ & $\begin{array}{c}\text { Pollen tube length } \\
2.5 \text { hours after } \\
\text { inoculation }\end{array}$ \\
\hline Control & $100 \mathrm{a}$ & $504 \mathrm{a}$ \\
\hline Propiconazole & $103.9 \mathrm{a}$ & $422 \mathrm{a}$ \\
\hline Benomyl & $96.3 \mathrm{a}$ & $453 \mathrm{a}$ \\
\hline Myclobutanil & $76.4 \mathrm{~b}$ & $459 \mathrm{a}$ \\
\hline Iprodione & $62.9 \mathrm{c}$ & $442 \mathrm{a}$ \\
\hline Thiophanate-methyl & $59.4 \mathrm{~cd}$ & $403 \mathrm{a}$ \\
\hline Maneb & $50.7 \mathrm{~d}$ & $165 \mathrm{~b}$ \\
\hline Cyprodinil & $30.2 \mathrm{e}$ & $163 \mathrm{~b}$ \\
\hline Ziram & $18.8 \mathrm{e}$ & $107 \mathrm{c}$ \\
\hline Azoxystrobin & $0.6 \mathrm{f}$ & $50 \mathrm{~d}$ \\
\hline Captan & $0.2 \mathrm{f}$ & $53 \mathrm{~d}$ \\
\hline
\end{tabular}

a Recommended field rate significantly affected by propiconazole and benomyl. Intermediate inhibitory effects on pollen germination were observed with ziram, cyprodinil, maneb, thiophanatemethyl, iprodione, and myclobutanil. In contrast to germination, tube growth was less affected by fungicides (Table 4). Again, azoxystrobin and captan reduced tube elongation by approximately to $90 \%$.

The above in vitro studies were also repeated under field conditions in an almond orchard ( $Y i$ et al., 2003c). In the almond orchard, fungicide sprays of azoxystrobin, myclobutanil, iprodione and cyprodinil did not affect pollen germination or tube growth significantly. Authors concluded that there are several other factors (e.g. cold stress, dry weather during flowering, nutritional deficiency, insect damage) which also influence pollen germination and they can mask fungicide spray results of pollination.

\section{Effect of insecticides and acaricides on flower formation and fertility}

Detrimental effects of insecticides, acaricides or other chemical compounds on pollen germination, fruit set, and/or yield were reported on apple (Mayer \& Lunden, 1986; Bound \& Jones, 2004; Nichols et al., 2004). Mayer \& Lunden (1986) noted that acaricides used during bloom influenced pollen viability of apple and pear. Nichols et al. (2004) determined the effect of ammonium thiosulphate and mineral oil applied with carbaryl on blossom properties of the apple cv. 'Northern Spy'. The results showed that fruit abscission and average fruit weight were enhanced by mineral oil applied with carbaryl. Bound \& Jones (2004) tested ammonium thiosulphate as a blossom thinner on 'Delicious' apple, 'Winter Cole' pear and 'Hunter' apricot. 4\%, ammonium thiosulphate was phytotoxic to the crops, resulting in severe burning of foliage and flowers. $1.5 \%$, ammonium thiosulphate reduced the crop load to an acceptable level without excessive damage. The $0.3 \%$ concentration was ineffective on cvs. 'Delicious' and 'Winter Cole'. Russet incidence was increased on 'Delicious' by the highest concentration applied at 20\% bloom. When ammonium thiosulphate was applied at $2.0 \%$ to 'Hunter' apricot at $20,40,60,80$ or $100 \%$ bloom, fruit set was reduced regardless of the time of application.

\section{Acknowledgements}

The study was supported by the National Scientific and Research Fund (F043503) and János Bolyai Research Fellowship.

\section{References}

Bound, S.A. \& Jones, K.M. (2004): Ammonium thiosulphate as a blossom thinner of 'Delicious' apple, 'Winter Cole' pear and 'Hunter' apricot Austr. J. Exp. Agric. 44: 931-937 
Brown, E.A. \& Hendrix, F.F. (1978): Effect of bloom of certain fungicides sprayed during apple bloom on fruit set and fruit rot. Plant Dis. Rep. 62: 739-741.

Butt, D. J., Swait, A.A., Joyce, J. \& Robinson, J.D. (1985): Effect of fungicides on germination of apple and pear pollen. Ann. Appl. Biol. 106: Supplement: 110-111.

Church, R.M., Cooke, B. K. \& Williams, R. R. (1983a): Testing the toxicity of fungicides to apple pollen. J. Hortic. Sci. 58: 161-163.

Church, R.M., Morgan, N.G., Cooke, B. K. \& Williams, R. R. (1983b): The effects of spray volume on the toxicity of captan and dinocap to apple pollen in the orchard. J. Hortic. Sci. 58: 165-168.

Church, R.M. \& Williams, R.R. (1977): Toxicity to apple pollens of several fungicides, as demonstrated by in vivo and in vitro techniques. J. Hortic. Sci. 52: 429-436.

Church, R.M. \& Williams, R.R. (1978): Fungicide toxicity to apple pollen in anther. J. Hortic. Sci. 53: 91-94.

Church, R.M. \& Williams, R.R. (1983): The effect of preblossom fungicide sprays on the ability of Cox Orange Pippin apple flowers to produce fruit. J. Hortic. Sci. 58: 169-172.

Cooley, D.R. (1991): Toxicity of fungicides to apple pollen. Fruit Notes. 56 (4): 18-19.

Cooley, D.R. \& Green, D.W. (1994): Do bloom application of apple fungicides affect fruit set? Fruit Notes. 59 (4): 15-16.

Eaton, G.W. (1961): Germination of sweet cherry (Prunus avium L.) pollen in vitro as influenced by fungicides. Canadian Journal of Plant Science. 41:740-743.

Fell, R.D., Rajotte, E.G. \& Yoder K.S. (1983): Effects of fungicide sprays during apple bloom on pollen viability and honey bee forging. Environmental Entomol. 12: 1572-1575.

He, Y. \& Wetzstein, H. Y. 1994. Pollen degeneration and retarded leaf development from fungicidal sprays applied during microscope development and shoot expansion. J. Hortic. Sci. 69: 975-983.

Kubik, M., Nowacki, J., Pidek, A., Warakomska, Z., Michalczuk, L., Goszczynski, W. \& Dwuznik B 2000. Residues of captan (contact) and difenoconazole (systemic) fungicides in bee products from an apple orchard. Apidologie. 31: 531-541.
Legge, A.P. \& WILLIAMS, R.R. (1975): Adverse effects of fungicidal sprays on pollination of apple flowers. J. Hortic. Sci. 50 (3): 275-279.

Marcucci, M.C. \& Filiti, N. (1984): Germination of pear and apple pollen as influenced by fungicides. Gartenbauwissenchaft. 49: 29-32.

Mayer, D.F. \& Lunden, J.D. (1986): Toxicity of fungicides and an acaricide to honey-bees (Homoptera, Apidae) and their effects on bee foraging behavior and pollen viability on blooming apples and pears. Environmental Entomol. 15: 1047-1049.

Nichols, D., Embree, C., Cline, J. \& Ju, H.Y. (2004): Blossom and fruitlet thinners affect crop load, fruit weight, seed number, and return bloom of 'northern spy' apple HortScience. 39: 1309-1312.

Olien, W.C., Miller, R.W., Graham, C.J., Taylor, E.R. \& Hardin, M.E. (1995): Effects of combined applications of ammonium thiosulphate and fungicides on fruit load and blossom blight and their phytotoxicity to peach trees. J. Hortic. Sci. 70: 847-854.

Ries, S.M. (1978): Germination of apple pollen as influenced by fungicides. Fruit Varieties J. 32 (1): 12-16.

Watters, B. S. \& Sturgeon, S. R. (1990): The toxicity of some foliar nutrients and fungicides to apple pollen cv. Golden Delicious. Tests of agrochemicals and cultivars. Ann. Appl. Biol. 116 Supplement: 70-71.

Wetzstein, H. Y. (1990): Stigmatic surface degeneration and inhibition of pollen germination with selected pesticidal sprays during receptivity in pecan. J. Am. Soc. Hortic. Sci. 115: 656-661.

Yi, W.G. Law SE, Wetzstein, H.Y. (2003a): Fungicide sprays can injure the stigmatic surface during receptivity in almond flowers. Ann. Bot. 91: 335-341.

Yi, W.G., Law, S.E., Wetzstein, H.Y. (2003b): An in vitro study of fungicide effects on pollen germination and tube growth in almond. HortScience. 38: 1086-1088.

Yi, W.G., Law, S.E., Wetzstein, H.Y. (2003c): Pollen tube growth in styles of apple and almond flowers after spraying with pesticides. J. Hortic. Sci. Biotechnol. 78: 842-846. 